\title{
E-Banking and mobile banking effects on customer satisfaction
}

\author{
Osly Usman $^{\mathrm{a}^{*}}$, Terrylina A Monoarfa ${ }^{\mathrm{a}}$ and Marsofiyati ${ }^{\mathrm{a}}$
}

\begin{tabular}{l}
${ }^{a}$ Faculty of Economic. Universitas \\
\hline C H R O N I C L E \\
\hline Article history: \\
Received May 152020 \\
Received in revised format May \\
162020 \\
Accepted July 62020 \\
Available online \\
July 102020 \\
\hline Keywords: \\
Gender \\
Effort Expectancy \\
Social Influence \\
Behavior Intention Behavior
\end{tabular}

\section{Introduction}

Currently, banking products continue to evolve in line with technological developments. Previously, customers had to come directly to the bank counter to deposit and withdraw money, this time these activities can be performed anywhere via electronic banking (e-banking). The use of e-banking products aims to reduce transaction costs, create free and easy way of transaction in which they are located. According to Bank Indonesia, e-banking can be categorized into 4 product services, such as internet banking, mobile banking, phone banking, and SMS banking. Banks in Indonesia can be divided into five categorizes based on capital ownership. The fifth category of banks is state banks, national private banks, foreign private banks, joint venture banks, and local government banks. During the period 2009-2015, the government did not focus on the bank's e-banking, it is seen from the data issued by Bank Indonesia which showed the level of the transaction by e-banking. The government banks are only $30 \%$ of the total banks in Indonesia. INDONESIA government banks are the Bank Negara Indonesia 46 (BNI 46), the State Savings Bank (BTN) and Bank Rakyat Indonesia (BRI). Excellence M-banking is for customers who do not need to use the ATM or the bank to conduct banking transactions such as transferring money, check balances, or bill payment (except cash withdrawals). Customers need to get easiness in obtaining financial information and conduct transactions online, especially for those who have a high mobility rate. The advantage of M-banking is the security (security) user-id that not everyone can know except the owner. Advantages possessed by the M-banking, make sure banks more attractive for customers by providing similar

* Corresponding author

E-mail address: Oslyusman@unj.ac.id (O. Usman)

(C) 2020 by the authors; licensee Growing Science, Canada doi: $10.5267 /$ j.ac.2020.7.006 
services. Despite the benefits provided there are still a few customers who use M-banking. Momani's study of the evolution theory of technology acceptance confirms that the failure of adaptation technologies tend to correlate with aspects of behavior (behavioral) (Momani \& Jamous, 2017), which is the behavior of an individual response or reaction to stimuli or environmental. Individuals who act as consumers have the right to accept or reject a product. Rejection or acceptance of a product is one manifestation of consumer behavior. Consumer behavior theory to explain the process of the actions of consumers is affected by a case to produce multiple outputs. Howard (1967) explains that the theory of consumer behavior can be seen from the process, which is input in the form of marketing and environmental stimuli which will produce output in the form of attitudes (attitudes toward a behavior), interest (intention), and buying behavior (purchase behavior). Research on the acceptance of the technology has been widely applied. Various theories and modeling acceptance of technology have also been evolved. Venkatesh et al. $(2003,2012 a, b, c)$ state there are several theories about the acceptance of the technology, including the Theory of Reasoned Action (TRA), the Technology Acceptance Model (TAM), Motivation Model (MM), Theory of Planned Behavior (TPB), Combined TAM and TPB (C-TAM-TPB), Model of PC Utilization (MPCU), Innovation Diffusion Theory (IDT), Social Cognitive Theory (SCT) and the Unified Theory of Acceptance and Use of Technology (UTAUT). UTAUT models of excellence that has been widely used as a model of technological acceptance of e-banking in the various banks make researchers interested in studying this topic in the context of state banks in Jakarta. In this research, the researchers added the security variable which correlates to behavior intention.

\section{Theoretical review}

\subsection{Theory of Reasoned Action (TRA)}

The general theory was developed based on the findings of social psychological research. Davis, et al. (1989, 1992). TRA has examined the use of models in a range of case studies of technology acceptance, and found that the TRA is relatively consistent for many case studies (Davis, 1989a,b). There are two constructs a model in this research, Attitude Toward Behavior (Attitude affects Conduct) and the Subjective Norm (Norma Subjective). Attitude Toward Behavior (Attitude affects Behavior) is defined as the perception of good and bad (affective factors) when evaluating a person in terms of influence on a person's behavior (Fishbein \& Ajzen, 1974), while Subjective Norm (Subjective Norms) are the norms that govern the rules (Fishbein \& Ajzen, 1974),

\subsection{Technology Acceptance Model (TAM)}

TAM is specifically designed as a model predictive analytics acceptance of information technology, especially the application of these technologies in the workplace. In contrast to the TRA, TAM precisely discards the concept of 'attitude' in the TRA to make room for intention, or deliberate action users (users of technology) in accepting new technology. While TAM version 2 (TAM2), was developed to include the Subjective Norm on TRA as a predictor in the work environment which has a strict operational standard (acceptance of technology is imposed). Both TAM and TAM2 has been used in a variety of case studies of technology acceptance (Venkatesh et al., 2003). The construct of TAM in this study includes Perceived usefulness (Perception Usability) and the Subjective Norm. Perceived of usefulness can be interpreted as a confidence level a person against a technology where the technology can be relied upon to help job (Davis, 1989a), Perceived of Ease of Use can be defined as a person's level of confidence against a technology where the technology is easy to use even do not need to learn / less effort ( Davis, 1989). Adaptation of the TRA is used as a predictor in the work environment which has a strict operational standard (acceptance of technology is imposed)

\subsection{Motivational Model (MM)}

In general, this model was developed based on some of the findings of psychological research related to motivation. In the context of information technology acceptance, Venkatesh and Speier (1999) study the use of these models in a variety of case studies and found that this model successfully explains the acceptance of these technologies. The perception of the intrinsic value that can be obtained by someone after acting. Satisfaction, and happiness (Davis et al., 1992) are in line with the definition of Attitude Toward Behavior at the TRA, but this constructs Attitude Toward Behavior dimension Compatibility Value, or matches the value of a person against technology. In the model of TPB, Subjective Norm is expanded in two dimensions, the influence of peers (peer influence) and the influence of the superior (superior influence). The perception of the user (user technology) will be difficult or easy mastery of the technology is based on habit today (Ajzen, 1991). In the context of information technology acceptance, it can be expressed as the perception of any obstacles that may be encountered in the user using the information technology products (Taylor \& Todd, 1995b)

\subsection{Theory of Planned Behavior (TPB)}


TPB is a development of TRA in the context of controlled behavior. TPB is also often called the expansion of the TRA which is patterned dimensionally. Perceived Behavioral Control added TPB as additional predictors. TPB constructs models include Attitude Toward Behavior, Subjective Norm, Perceived Behavioral Control. Definition of Attitude Toward Behavior on TRA together with other variables. In the model of TPB, Norm Subjective indicators is expanded in two dimensions, the influence of peers (peer influence) and the influence of the superior (superior influence). Perception users (users of technology) will be difficult or easy mastery of the technology is based on habit today (Ajzen, 1991). In the context of information technology acceptance, it can be expressed as the perception of any obstacles that may be encountered in the user using the information technology products (Taylor \& Todd, 1995b),

\subsection{Combined TAM and TPD (C-TAM-TPB)}

This model combines the predictors of TPB with Perceived Usefulness on TAM and becomes a hybrid model of reception technology (Taylor \& Todd, 1995). This model also expands the definition of Perceived Behavioral Control in three dimensions, i.e. the perception of the ability of self (self-efficacy), the conditions supporting resources (resource facilitating condition), and the condition of the supporting technology (technology facilitating conditions). The construct models of the C-TAM-TPB is Attitude Toward Behavior, Subjective Norm, Perceived Behavioral Control and Perceived Usefulness. In line with the definition of Perceived Behavioral Control on TPB, but expanded into three dimensions; namely self-perception abilities (self-efficacy), the conditions supporting resources (resource facilitating condition), and the condition of the supporting technology (technology facilitating conditions).

\subsection{Model of PC Utilization (MPCU)}

This model was developed by Thompson et al. (1991), the behavior of the use of a PC (Personal Computer) is based on the findings of psychological research of human behavior by Triandis et al. (1990), especially regarding social norms (social norm), habits (habit), and expectations related to the consequences of the action (expected consequences). Although designed to observe the behavior of the use of a PC, MPCU is also still relevant to research in the general acceptance of information technology (Venkatesh et al., 2003) as "Confidence of someone that the use of these technologies can help and improve work performance" (Thompson, Higgins, \& Howell, 1991), Constructs of MPCU models include the Job-fit (Compatibility with Jobs), Complexity (Complexity), Long-term Consequences (Konsekusensi Term), Towards Affect Use (Affective Encouragement to use), Social Factors (Social Factors), Facilitating Conditions (conditions- Supporting conditions). Job-fit (Compatibility with Jobs) and is defined as "a person's belief that the use of these technologies can help and improve work performance" (Thompson et al., 1991). According to Shoemaker (1971) in Thompon, et al. (1991) Complexity (Complexity) is defined as "the perception of the ease of technology can be understood and used" (Thompson et al., 1991). Long-term onsequences (Konsekusensi Term) About the results to be obtained in the future (Thompson et al., 1991). Affect Towards Use (Encouragement Affective to use) is defined by Triandis (1991), Affect Towards the Use as "a feeling of joy, joy, favor, or otherwise as depression, confusion, no favors even hate that can be associated with specific decisions a person to take action" (Thompson et al. , 1991). Social Factors (Social Factor) is "someone internalizes against some subjective opinions, and specifically may be approval interpersonal person with another person, in specific social situations" according to Thompson et al. (1991). Facilitating Conditions (Conditions Support) include factors such as service or function in the product that makes the product be easily accepted. As a free service of purchase if the product is disappointed in online transactions (Thompson et al., 1991).

\subsection{Innovation Diffusion Theory (IDT)}

IDT was developed through a research method of Grounded Theory in sociology. Rogers in Tomatzky and Klein (1982) observes that IDT has been used since the 1960s for innovation survey of various technologies, ranging from agriculture to the company (Tornatzky \& Klein, 1982) where in the context of information systems, Moore and Benbasat (1991) adapt the characteristics of exposure to the construction of a suitable model for individual technology reception research, especially in the aspect of valid predictive (Moore \& Benbasat, 1991), The construct models Innovation Diffusion Theory (IDT) is described in Table 1.

\section{Table 1}

Constructs Innovation Model Diffusion Theory (IDT)

Relative Advantage The perception that new technologies offered are superior relative to the previous technology (G. Moore \& Benbasat, (Advantage Relative) 1991),

Ease of Use (Ease of Use) Perception of the degree of difficulty of use of a technology (G. Moore \& Benbasat, 1991), Image (Image) The perception that the use of these technologies can improve the image (image) users (G. Moore \& Benbasat, 1991)

Visibility (Visibility) The perception that technology has become public or used in bulk by the public ((GC Moore \& Benbasat, 1991)). Compatibility The perception that technology is consistent with the values, needs, to the user's experience (adopter) potential (GC Moore (Compatibility Values) \& Benbasat, 1991), 


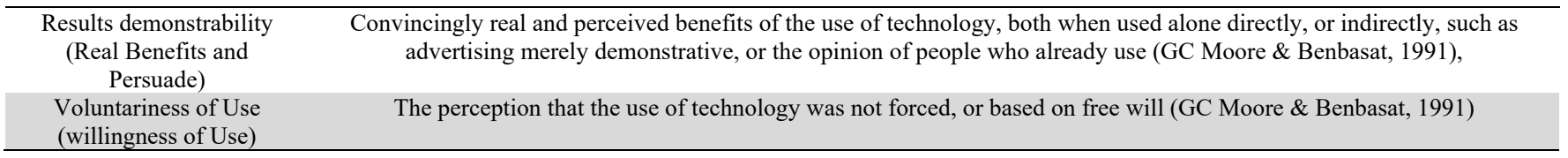

\subsection{Social Cognitive Theory (SCT)}

Developed based on Social Cognitive Theory of psychological research by Albert Bandura. Compeau and Higgins then develop models of SCT in the context of computer technology acceptance(Compeau \& Higgins, 1995), Similar to MPCU and IDT, although Compeau and Higgins initially develop this model in the context of computer technology acceptance, but this model is still relevant to the context of the general acceptance of information technology (Venkatesh et al., 2003; Sinisalo \& Karjaluoto, 2009; Mukherjee \& Nath, 2003), The construct models Innovation Diffusion Theory (IDT) is described in Table 2.

Table 2

Model Construct Social Cognitive Theory (SCT)

\begin{tabular}{|c|c|}
\hline $\begin{array}{l}\text { Outcome Expectation performance (Expected } \\
\text { Results Over Usage Habits) }\end{array}$ & $\begin{array}{l}\text { Performance can be achieved over-usage habits. Specifically can be defined as well as the expected } \\
\text { performance of technologies following the increasingly untrained user, especially in the completion of } \\
\text { work tasks (Compeau \& Higgins, 1995) }\end{array}$ \\
\hline $\begin{array}{l}\text { Outcome Expectations Personal (Personal } \\
\text { Expectations Will Use of Technology) }\end{array}$ & Personal expectations for the use of technology, such as satisfaction (Compeau \& Higgins, 1995) \\
\hline Self-efficacy (Personal Testing) & $\begin{array}{l}\text { Results of testing one's judgment on whether or not a technology capable help finishes the job } \\
\text { (Venkatesh, 2003). }\end{array}$ \\
\hline $\begin{array}{l}\text { Affect (Personal Assessment Based on } \\
\text { Affection) }\end{array}$ & $\begin{array}{l}\text { Personal assessment by affection or love someone whether or not he on the use of a technology } \\
\text { (Compeau \& Higgins, 1995), }\end{array}$ \\
\hline Anxiety (Anxiety) & The reaction of anxiety when going habits (Compeau \& Higgins, 1995a), \\
\hline
\end{tabular}

\section{Framework}

\subsection{The relationship between Performance Expectancy and Behavioral Intention}

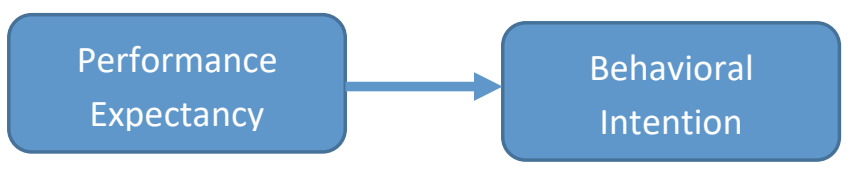

Fig. 1. Relations expectancy performance and behavioral intention Source (Tahrini, 2015)

According to Venkatesh (2012), performance expectancy is the level of confidence that the use of technology will give us an advantage to conduct certain activities. These variables affect the behavioral intention. Performance expectancy in this study reflects the level of confidence that the use of e-banking will increase profits in banking transactions. Performance expectations in the use of e-banking will increase effusions and effectiveness in banking services. In other words, the use of internet banking will result in increased performance expectations, which will affect the intent of the behavior (Zhou, Lu, \& Wang, 2010), in this case the performance expectancy in banking cars that have big risk will affect users in using Mobile Banking(Raza et al., 2017),

\subsection{Relationship between Effort Expectancy and Behavioral Intention}

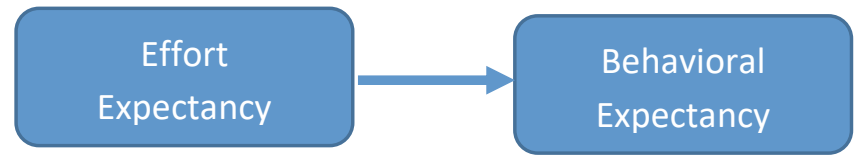

Fig. 2 Relations effort expectancy and behavioral intention Source (Tahrini, 2015)

According to Venkatesh et al. (2012), Effort expectancy is the level of ease in the use of technology. These variables affect the behavioral intention. Effort expectancy in this study reflects the degree of ease of use of e-banking. The convenience level will 
affect the level of desire to continue using e-banking. Another important indicator is the user desires in trying referring to the perception of intentions into user behavior that requires minimal effort in the application of technology use (Doll \& Torkzadeh, 1988), Desire users in the ease of adapting certain technologies into existing work routines. For example, the user desires to rise easily when using the technology following what is desired in the behavior of the user intent (Lee, 2009), Measure of user interest would affect behavioral intentions, in that it would allow financial institutions to redesign e-banking business plans to improve the operation and design of their site (Ganapathy et al., 2004), In this study, researchers define the level of ease in the use of e-banking technology will affect behavioral intentions in using the technology to perform the transaction.

\subsection{The relationship between Social Influence and Behavioral Intention}

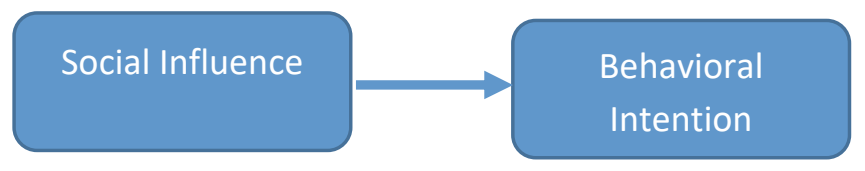

Fig. 3. Social Relationships Influence and Behavioral Intention Source (Tahrini, 2015)

According to Venkatesh et al. (2012), Social influence is the user's perception of the people who are important to him to convince that he should use the technology. This variable affects the behavioral intention (the level of interest in using technology) ebanking. The use of technology in one's social environment will affect the person's reputation. Users will follow circles people using the internet by the intentions of behavior (Gounaris \& Koritos 2008). Support the social influence of the environment is important to introduce e-banking to non-e-banking users in an organization. The high degree of interdependence among workers in carrying out certain tasks, social support from colleagues is essential for the achievement of specific objectives such as increased productivity in a organization in accordance with the worker's behavior intention in the use of e-banking(Lee, 2009) In this study, researchers defined social influence will have a stronger effect on the users of technology where social influence is very important in the early stages of technology acceptance. Support social influence will affect the Mobile Payment in transactions conducted by using a smartphone with NFC for relations interest in the use of information technology behavioral intention(Teo, Tan, Ooi, Hew, and Yew, 2015; Wold, 1980; Sinisalo \& Karjaluoto, 2009)

\subsection{The relationship between Facilitating Conditions and Behavioral Intention}

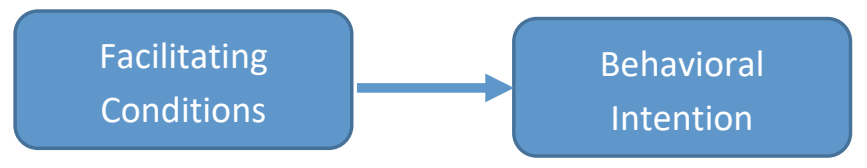

Fig. 4. Facilitating relationships Condition and Behavioral Intention Source (Tahrini, 2015)

According to Venkatesh et al. (2012), Facilitating Conditions is user perception related to the availability of resources and encouragement to make use of. These variables affect the Behavioral Intention (level of desire to continue to use the technology). Facilitating Conditions in this study, indicating that the user perception related to the availability of resources and the promotion of the use of e-banking. This perception level will affect the level of desire to continue to use e-banking. Facilitating conditions are further indicators that have a direct effect on the acceptance of e-banking.

\subsection{The relationship between Security and Behavioral Intention}

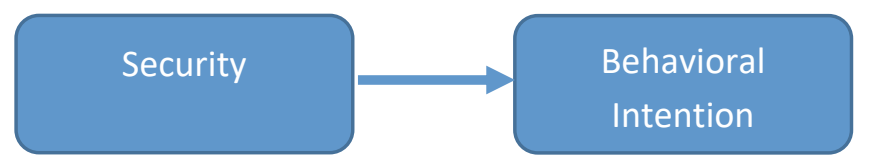

Fig. 4. Security relations and Behavioral Intention Source (Tarhini et al., 2016)

According to Venkatesh et al. (2012) security comes from the use of technology. These variables affect the Behavioral Intention. Security in this study reflects the security that comes from the use of e-banking. Security will affect the level of desire to continue 
using e-banking. Security cannot get away from privacy. Privacy issues have been shown to be an important barrier for online services (Hernandez \& Afonso Mazzon, 2007; Mauro et al., 2007), e-banking security is defined as the threat of creating a "state, condition or event with the potential to cause difficulty to obtain data or network resources that make destruction, disclosure, modification of data, fraud and abuse". Consumer perceptions of online security pose a different perception. Measuring the level of security that objective in every transaction does not easily correspond to consumers' perception of security (Chellappa \& Pavlou, 2002),

\subsection{The relationship between Behavioral Intention and Use Behavior}

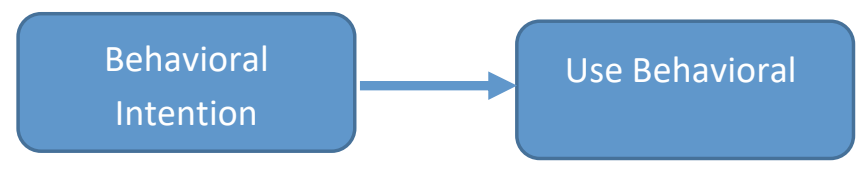

Fig. 5. Relations Behavioral Intention and Use Behavior Source (Tarhini et al., 2016)

Behavior use of information technology (user behavior) is defined as the intensity or frequency of the user in the use of information technology. Triandis et al. (1990) stated that the behavior of a person's behavior is an expression of a person's desire or interest (intention), where the desire is influenced by social factors, feeling (Affect), and the perceived consequences (perceived consequences). Behavior use of information technology is very dependent on the user evaluation of the system. Thus, the use of the system is an indicator of the performance assessment of the use and acceptance of information technology. Good or bad information technology depends on what is perceived by the user. Empirically, the relationship with the usage behavior interest in the use of technology has been proven in several studies (Thompson et al., 1991). Venkatesh et al. (2003) also found the same thing, that there is a direct and significant relationship between the interests of information technology (Behavioral Intention) on the use of information technology (Use behavior). The same thing was also illustrated by (Martins, Oliveira, and Popovic, 2014) which states that the behavioral intention to have a strong relationship with the use behavior that is marked with $\mathrm{R} 2=0.98$ which means it has a very strong relationship Behavior Intention in E-commerce also has a strong relationship to Use Behavior in the purchase of goods by using model UTAUT in Ghana (Ofori, Boakye, Addae, Ampong, \& Adu, 2017),

\section{Research methodology}

Methods of data analysis in this study using SEM-PLS is a modeling software (soft modeling), this method is not too tight on the fulfillment of assumptions as to the method of SEM. This method is an applicable method, especially for research applications field, which is quite difficult to meet the rigorous modeling assumptions, such as the adequacy of the sample size, the error distribution assumptions should follow the multivariate normal distribution and homogeneous(Monecke \& Leisch, 2012; Henderson, 1995). According to Tenenhaus et al. (2005) SEM-PLS models are based on three main components, namely the structural model (structural model), the measurement model (measurement model) and also the weighting scheme (weighting). A structural model is a model that describes the relationship between latent variables based on substantive theories. The measurement model is a model that describes the relationship between the latent variables with indicator variables.

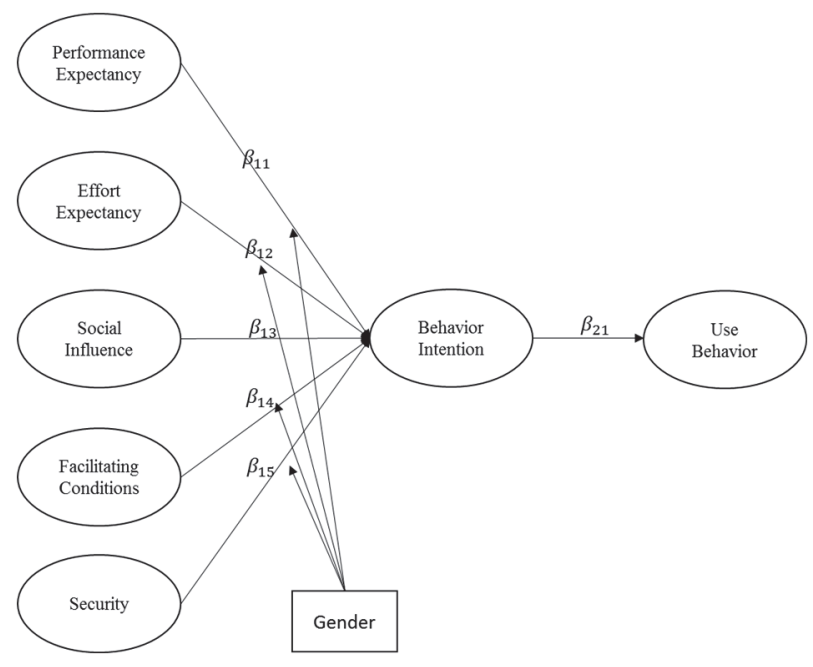

Fig. 6. Research constellation 
Variables are defined as anything that can distinguish or bring variation in value. Values can be different at different times for the same object or person, or at the same time for different objects(Have now \& Bougie, 2016). The variables in this study consist of five independent variables and two dependent variables. Independent variables include performance expectancy, effort expectancy, social influence, facilitating conditions and security, among other dependent variables behavioral intention and use behavior. In this study Gender is suspected as a moderating variable on Performance Expectancy, Effort Expectancy, Facilitating Condition, Security on Behavioral Intention to the government banks. To determine the significant influence of gender as a moderating variable of performance expectancy, effort expectancy, facilitating condition, security for the Behavioral Intention are used in multi-group analysis (MGA). There are two groups which were analyzed, namely a group of men and women groups. The definition of variables and items used to measure variables in (Venkatesh et al., 2012b).

Table 3

Variable Operationalization

\begin{tabular}{|c|c|c|c|}
\hline variables & variable definition & Dimension & Indicator \\
\hline $\begin{array}{l}\text { performance } \\
\text { Expectancy } \\
(\mathrm{PE})\end{array}$ & $\begin{array}{l}\text { The level of confidence } \\
\text { that the use of } \\
\text { electronic banking } \\
\text { would improve } \\
\text { efficiency in the } \\
\text { transaction. }\end{array}$ & $\begin{array}{l}\text { 1. Expectations of electronic } \\
\text { banking technology }\end{array}$ & $\begin{array}{l}\text { 1) Perceptions of users } \\
\text { 2) Extrinsic Motivation } \\
\text { 3) suitability jobs } \\
\text { 4) Relative Advantages } \\
\text { 5) expectations Results }\end{array}$ \\
\hline $\begin{array}{l}\text { effort Expectancy } \\
\text { (EE) }\end{array}$ & $\begin{array}{l}\text { The level of ease of use } \\
\text { of the electronic } \\
\text { banking system. }\end{array}$ & 1. Ease Using e-banking & $\begin{array}{l}\text { 1) Ease of users to understand the e- } \\
\text { banking } \\
\text { 2) Ease of interaction with e-banking } \\
\text { 3) Ease of users to do e-banking } \\
\text { 4) Ease users to operate e-banking }\end{array}$ \\
\hline $\begin{array}{l}\text { Social Influence } \\
\quad \text { (SI) }\end{array}$ & $\begin{array}{l}\text { Perception users } \\
\text { against people who are } \\
\text { important to him to } \\
\text { convince he must use } \\
\text { the electronic banking }\end{array}$ & 1. Factors social factor & $\begin{array}{l}\text { 1) Influence others } \\
\text { 2) Effect of bank management } \\
\text { 3) The influence of the workplace } \\
\text { 4) The influence of psychographic } \\
\text { (prestige) }\end{array}$ \\
\hline $\begin{array}{c}\text { facilitating } \\
\text { Conditions } \\
\text { (FC) } \\
\text { Thompson, et al. } \\
\text { (1991) }\end{array}$ & $\begin{array}{l}\text { User perception related } \\
\text { to the availability of } \\
\text { resources and } \\
\text { encouragement to use } \\
\text { banking electronic }\end{array}$ & $\begin{array}{l}\text { 1. The availability of } \\
\text { resources and boost the } \\
\text { use of electronic banking }\end{array}$ & $\begin{array}{l}\text { 1) Perceived behavioral control } \\
\text { 2) Conditions affecting -condition } \\
\text { 3) Compatibility using Electronic } \\
\text { Banking }\end{array}$ \\
\hline $\begin{array}{l}\text { Security } \\
\text { (S) }\end{array}$ & $\begin{array}{c}\text { Security level } \\
\text { electronic banking } \\
\text { system }\end{array}$ & $\begin{array}{l}\text { 1. Security of use of the } \\
\text { electronic banking system }\end{array}$ & $\begin{array}{l}\text { 1) Privacy } \\
\text { 2) Authentication } \\
\text { 3) Integrity } \\
\text { 4) Non-repudiation }\end{array}$ \\
\hline $\begin{array}{l}\text { behavioral } \\
\text { Intention } \\
\quad \text { (BI) }\end{array}$ & $\begin{array}{l}\text { Level of desire to } \\
\text { continue using the } \\
\text { electronic banking } \\
\text { system }\end{array}$ & $\begin{array}{l}\text { 1. Interest in the use of } \\
\text { electronic banking system }\end{array}$ & $\begin{array}{l}\text { 1) The use of e-banking interest } \\
\text { 2) Increased efficiency increase } \\
\text { 3) Increasing the effectiveness of } \\
\text { 4) Improved performance of service }\end{array}$ \\
\hline $\begin{array}{l}\text { Use behavior } \\
\text { (USE) }\end{array}$ & $\begin{array}{c}\text { Electronic banking } \\
\text { system usage behavior }\end{array}$ & $\begin{array}{l}\text { 1. Behavior use the } \\
\text { electronic banking system }\end{array}$ & $\begin{array}{l}\text { 1) Frequency of users in using } \\
\text { information technology } \\
\text { 2) Social factors } \\
\text { 3) Feelings (Affect) } \\
\text { 4) level of Satisfaction }\end{array}$ \\
\hline gender & $\begin{array}{l}\text { The nature or state of } \\
\text { the male or female }\end{array}$ & 1. Gender & $\begin{array}{l}\text { 1) Male } \\
\text { 2) woman } \\
\end{array}$ \\
\hline
\end{tabular}

\section{Results and discussion}

Outer model is presented in Table 4 . The table illustrates the convergent validity test to examine the validity and reliability tests with reliability and Cronbach alpha compositing. Indicator or indicators inferred valid if it has a loading value above 0.5. Indicator or indicators measuring the latent variables inferred reliably if the value of composite reliability Cronbach alpha above 0.7 and above 0.6 . 
Table 4

Outer Models With Gender As Moderating Variables

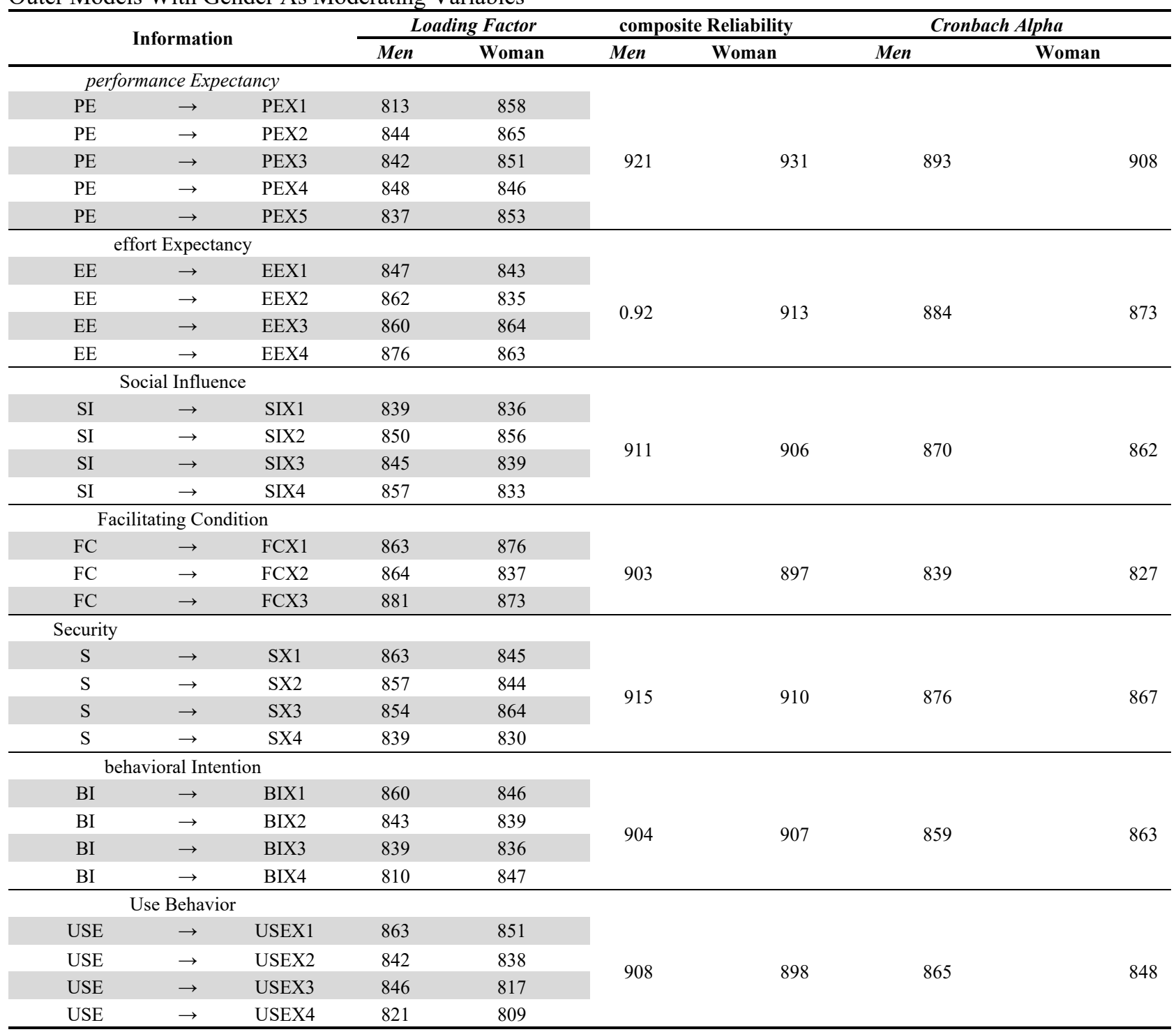

Source: Processed Data Statistics

Table 4 shows that all indicators at each latent variable have a value of more than 0.5 loadings. There is no significant difference in value loading in men and women. Reliability of composite value of more than 0.7 and Cronbach alpha values of more than 0.6 assure there is no difference in the level of validity and reliability of measuring instruments for both men and women.

Table 5

Influence Coefficients gender as moderating variables of Performance Expectancy, Effort Expectancy, Facilitating Condition, Security on Behavioral Intention

\begin{tabular}{|c|c|c|c|c|c|c|c|}
\hline \multirow{2}{*}{\multicolumn{3}{|c|}{ directions relationship }} & \multicolumn{2}{|c|}{ Coefficient } & \multirow{3}{*}{$\begin{array}{c}\text { Difference } \\
0126\end{array}$} & \multirow{3}{*}{$\frac{\text { t-test }}{2: 03}$} & \multirow{3}{*}{$\begin{array}{c}\text { P-Value } \\
0047\end{array}$} \\
\hline & & & \multirow{2}{*}{$\begin{array}{r}\text { Men } \\
0239\end{array}$} & \multirow{2}{*}{$\begin{array}{c}\text { Woman } \\
0045\end{array}$} & & & \\
\hline performance expectancy & $\rightarrow$ & behavioral Intention & & & & & \\
\hline effort expectancy & $\rightarrow$ & behavioral Intention & 0186 & 0035 & 0151 & 2.87 & 0035 \\
\hline Facilitating condition & $\rightarrow$ & behavioral Intention & 0083 & 0197 & 0114 & 1.99 & 0049 \\
\hline Security & $\rightarrow$ & behavioral Intention & 0335 & 0193 & 0142 & $2: 56$ & 0039 \\
\hline
\end{tabular}

Source: Processed Data Statistics

In this study, the research hypothesis assumed that gender is a moderating variable of performance expectancy, effort expectancy, facilitating condition, security against behavioral intention. The findings turned out to show that gender is 
moderating variable on performance expectancy, effort expectancy, facilitating condition and security in e-banking technology adoption in government bank customers.

- $\quad \mathrm{H}_{0}$ : There is no difference in the effect of performance on Behavioral Intention expectancy between men and women.

- $\quad$ H1: There is a difference in influence performance on Behavioral Intention expectancy significantly between men and women.

Tests carried out using a parametric approach (t-test). The T-test in this study was drawn from the differences in the effect of performance on Behavioral Intention expectancy at 2.03 with a p-value 0.047 which is less than the value of $\alpha=0: 05$. Thus, we can accept H1. This means that there are significantly differences in the effect of performance on Behavioral Intention expectancy between men and women.

- $\quad \mathrm{H}_{0}=$ There is no difference in the effect of the effort against the Behavioral Intention expectancy significantly between men and women.

- $\quad \mathrm{H}_{1}$ : There is a difference of influence expectancy effort to Behavioral intention significantly between men and women.

Tests carried out using a parametric approach (t-test). Table 5 shows that the value of the t-test of differences in the effect of the Behavioral Intention effort expectancy at 2.87 with a p-value 0.035 which is less than the value of $\alpha=0: 05$. Thus, we can accept $\mathrm{H}_{1}$, which means that there are significantly differences in the effect of the Behavioral Intention effort expectancy between men and women.

- $\quad \mathrm{H}_{0}=$ There is no difference in the effect of facilitating conditions on Behavioral Intention significantly between men and women.

- $\quad \mathrm{H}_{1}$ : There is a difference in the effect of facilitating conditions on Behavioral Intention significantly between men and women.

Tests carried out using a parametric approach (t-test). Table 5 shows the value of the t-test of differences in the effect of facilitating condition on Behavioral Intention of 1.99 with a $p$-value 0.049 or less than the value of $\alpha=0: 05$ and we can accept H1. This means that there are differences in the effect of facilitating condition on Behavioral Intention significantly between men and women.

- $\quad \mathrm{H}_{0}=$ There is no difference in the effect of security for the Behavioral Intention significantly between men and women.

- $\quad \mathrm{H}_{1}$ : There is a difference in the effect of security for the Behavioral Intention significantly between men and women

Table 5 shows the value of the t-test of differences in the effect of security for the Behavioral Intention of 2.56 with a p-value 0.039 which is less than the value of $\alpha=0.05$ and we accept H1. This means that there are differences in the effect of security for Behavioral Intention significantly between men and women.

Based on the research that has been concluded above, we reach very important implications for the promotion of Use Behavior Intention Behavior through the acceptance of the technology of e-banking customers of banks the government in Jakarta.

\section{Conclusion}

Based on the findings and conclusions, this study raises some theoretical implications as follows:

1. Improved performance Expectancy, Effort Expectancy, Social Influence, Condition, and Security Facilitating will upgrade Behavior Intention Behavior Use both directly and indirectly, which means that if we want to upgrade Behavior Intention and Use Behavior then we need to increase that variable.

a. Efforts to do in improving the performance Expectancy acceptance of the technology of e-banking customers of banks the government, namely the perception of usage, extrinsic motivation, job suitability, the relative advantages, and expectations are the result.

b. Efforts should be made to improve Effort Expectancy, namely effect easy to understand electronic banking, the ability to use electronic banking, electronic banking ease of use and convenience to operate electronic banking.

c. Efforts to do that are by upgrading Social Influence, which affects others, the influence of the workplace, the influence of banks and the influence of environmental psychographic (prestige). 
d. Efforts should be made to improve Facilitating Condition, namely the perceived behavioral control upgrade (perceived behavioral control), conditions that facilitate (facilitating condition), and compatibility (compatibility conditions) using electronic banking.

e. Efforts to be made in improving security, by upgrade privacy, authentication, integrity, and non-repudiation.

2. Improved Behavior intention will upgrade to Use Behavior directly, meaning that if we want to upgrade to Use Behavior it is necessary first to improve the intention Behavior. Efforts to be made in increasing the frequency of increasing interest include banking transactions, interest on the efficiency of the time, interest in the effectiveness of, and the benefits of increased performance.

3. Another effort that can be done is improving the Use Behavior, namely by increasing the frequency of use, social factors (social factor), feelings (toward electronic banking Affect use), and the consequences are felt (evaluation of the use).

\section{Suggestion}

In this study, there were five independent variables including performance expectancy, effort expectancy, facilitating condition, social influences and security. The results have shown that security becomes the most important aspect in supporting the behavioral intention and the security aspects affect user behavior. To increase the trust of customers, the security of electronic banking should be maintained and improved. This study, by the methods of analysis, is quite complex, to enrich further research the structural equation model can be modified to incorporate a range of variables from previous researchers, to obtain findings more deeply and other development of methods UTAUT.

\section{References}

Ajzen, I. (1991). The theory of planned behavior. Organizational Behavior and Human Decision Proces, 50(2), 179-211.

Alalwan, A. A., Dwivedi, Y. K., Rana, N. P. P., \& Williams, M. D. (2016). Consumer adoption of mobile banking in Jordan. Journal of Enterprise Information Management, 29(1), 118-139. https://doi.org/10.1108/JEIM-04-2015-0035

Celik, H. (2016). Customer online shopping anxiety within the Unified Theory of Acceptance and Use Technology (UTAUT) framework. Asia Pacific Journal of Marketing and Logistics, 28(2), 278-307.

Chellappa, R. K., \& Pavlou, P. A. (2002). Perceived information security, financial liability and consumer trust in electronic commerce transactions. Logistics Information Management, 15(5/6), 358-368.

Chin, W. W. (2010). How to write up and report PLS analyses. In Handbook of partial least squares (pp. 655-690). Springer.

Compeau, D. R., \& Higgins, C. A. (1995a). Application of social cognitive theory to training for computer skills. Information Systems Research, 6(2), 118-143.

Compeau, D. R., \& Higgins, C. A. (1995b). Computer self-efficacy: Development of a measure and initial test. MIS Quarterly, 19(2), 189-211.

Davis, F.D., Bagozzi, R. P., \& Warshaw, P. R. (1989). User acceptance of computer technology: a comparison of two theoretical models. Management Science, 35, 982-1003. https://doi.org/10.1287/mnsc.35.8.982

Davis, Fred D. (1989a). Perceived usefulness, perceived ease of use, and user acceptance of information technology. MIS Quarterly, 13(3), 319-340.

Davis, Fred D. (1989b). Perceived usefulness, Perceived ease of use , and user acceptance. MIS Quarterly, 13(3), 319-339. https://doi.org/10.2307/249008

Davis, Fred D, Bagozzi, R. P., \& Warshaw, P. R. (1992). Extrinsic and intrinsic motivation to use computers in the workplace 1. Journal of Applied Social Psychology, 22(14), 1111-1132.

Doll, W. J., \& Torkzadeh, G. (1988). The measurement of end-user computing satisfaction. MIS Quarterly, 12(2), 259-274.

Fishbein, M., \& Ajzen, I. (1974). Attitudes towards objects as predictors of single and multiple behavioral criteria. Psychological Review, 81(1), 59.

Ganapathy, S., Ranganathan, C., \& Sankaranarayanan, B. (2004). Visualization strategies and tools for enhancing customer relationship management. Communications of the ACM, 47(11), 92-99.

Gounaris, S., \& Koritos, C. (2008). Investigating the drivers of internet banking adoption decision: A comparison of three alternative frameworks. International Journal of Bank Marketing, 26(5), 282-304.

Henderson, R. (1995). European retail banking: innovation strategies. International Journal of Business Studies, 3(1), 11-30.

Lee, M. C. (2009). Factors influencing the adoption of internet banking: An integration of TAM and TPB with perceived risk and perceived benefit. Electronic Commerce Research and Applications, 8(3), 130-141. https://doi.org/10.1016/j.elerap.2008.11.006

Martins, C., Oliveira, T., \& Popovič, A. (2014). Understanding the Internet banking adoption: A unified theory of acceptance and use of technology and perceived risk application. International Journal of Information Management, 34(1), 1-13.

Mauro, C., Hernandez, J., \& Afonso Mazzon, J. (2007). Adoption of internet banking: proposition and implementation of an 


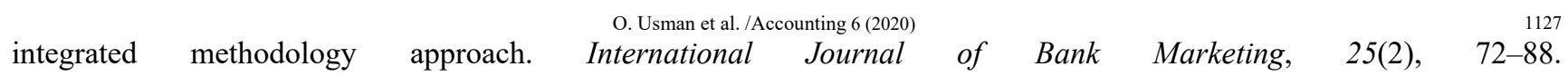
https://doi.org/10.1108/02652320710728410

Momani, A. M., \& Jamous, M. (2017). The Evolution of Technology Acceptance Theories.

Monecke, A., \& Leisch, F. (2012). PLS: structural equation modeling using partial least squares.

Moore, G., \& Benbasat, I. (1991). Development of an Instrument to Measure the Perceptions of Adopting an Information Technology Innovation. Information Systems Research, 2, 192-222. https://doi.org/10.1287/isre.2.3.192

Moore, G. C., \& Benbasat, I. (1991). Development of an instrument to measure the perceptions of adopting an information technology innovation. Information Systems Research, 2(3), 192-222.

Mukherjee, A., \& Nath, P. (2003). A model of trust in online relationship banking. International Journal of Bank Marketing, 21(1), 5-15. https://doi.org/10.1108/02652320310457767

Ofori, K. S., Boakye, K. G., Addae, J. A., Ampong, G. O. A., \& Adu, A. S. Y. (2017). An Empirical Study on the Adoption of Consumer-to-Consumer E-commerce: Integrating the UTAUT Model and the Initial Trust Model. International Conference on E-Infrastructure and e-Services for Developing Countries, 281-292. Springer.

Raza, S. A., Umer, A., \& Shah, N. (2017). New determinants of ease of use and perceived usefulness for mobile banking adoption. International Journal of Electronic Customer Relationship Management, 11(1), 44-65.

Sekaran, U., \& Bougie, R. (2016). Research methods for business: A skill building approach. John Wiley \& Sons.

Sinisalo, J., \& Karjaluoto, H. (2009). THE IMPACT OF MOBILE PHONE CAPABILITIES ON MOBILE SERVICE USAGE: EMPIRICAL EVIDENCE FROM FINLAND. International Journal of Mobile Marketing, 4(1).

Tan, E., \& Leby Lau, J. (2016). Behavioural intention to adopt mobile banking among the millennial generation. Young Consumers, 17(1), 18-31. https://doi.org/10.1108/YC-07-2015-00537

Tarhini, A., El-Masri, M., Ali, M., \& Serrano, A. (2016). Extending the UTAUT model to understand the customers' acceptance and use of internet banking in Lebanon. Information Technology \& People, 29(4), 830-849. https://doi.org/10.1108/ITP-022014-0034

Taylor, S., \& Todd, P. (1995a). Assessing IT usage: The role of prior experience. MIS Quarterly, 19(4), 561. https://doi.org/10.2307/249633

Taylor, S., \& Todd, P. A. (1995b). Understanding information technology usage: A test of competing models. Information Systems Research, 6,144-176. https://doi.org/10.1287/isre.6.2.144

Tenenhaus, M., Vinzi, V. E., Chatelin, Y. M., \& Lauro, C. (2005). PLS path modeling. Computational Statistics and Data Analysis, 48(1), 159-205. https://doi.org/10.1016/j.csda.2004.03.005

Teo, A.-C., Tan, G. W.-H., Ooi, K.-B., Hew, T.-S., \& Yew, K.-T. (2015). The effects of convenience and speed in m-payment. Industrial Management \& Data Systems, 115(2), 311-331. https://doi.org/10.1108/IMDS-08-2014-0231

Teo, A.-C., Tan, G. W.-H., Ooi, K.-B., \& Lin, B. (2015). Why consumers adopt mobile payment? A partial least squares structural equation modelling (PLS-SEM) approach. International Journal of Mobile Communications, $13(5), 478-497$.

Thompson, R. L., Higgins, C. A., \& Howell, J. M. (1991). Personal Computing: Toward a Conceptual Model of Utilization. MIS Quarterly, 15(1), 125. https://doi.org/10.2307/249443

Tornatzky, L. G., \& Klein, K. J. (1982). Innovation characteristics and innovation adoption-implementation: A meta-analysis of findings. IEEE Transactions on Engineering Management, 1, 28-45.

Triandis, H. C., McCusker, C., \& Hui, C. H. (1990). Multimethod probes of individualism and collectivism. Journal of Personality and Social Psychology, 59(5), 1006.

Turban, E., King, D., Lee, J., \& Liang, T. P. (2012). D. Turban (2012). Electronic Commerce 2012: A managerial and social networks perspective. Pearson.

Venkatesh, V., Morris, M. G., Davis, G. B., \& Davis, F. D. (2003). User acceptance of information technology: Toward a unified view. MIS Quarterly, 27(3), 425-478.

Venkatesh, V., \& Speier, C. (1999). Computer technology training in the workplace: A longitudinal investigation of the effect of mood. Organizational Behavior and Human Decision Processes, 79(1), 1-28.

Venkatesh, V., Thong, J., \& Xu, X. (2012a). Consumer acceptance and user of information technology: Extending the unified theory of acceptance and use of technology. MIS Quarterly, 36(1), 157-178. https://doi.org/10.1111/j.13652729.2006.00163.x

Venkatesh, V., Thong, J. Y. L., \& Xu, X. (2012b). Consumer Acceptance and Use of Information Technology : Extending the Unified Theory. MIS Quarterly, 36(1), 157-178. https://doi.org/10.1017/CBO9781107415324.004

Venkatesh, V., Thong, J. Y. L., \& Xu, X. (2012c). Consumer acceptance and use of information technology: extending the unified theory of acceptance and use of technology. MIS Quarterly, 36(1), 157-178.

Wold, H. (1980). Model construction and evaluation when theoretical knowledge is scarce: Theory and application of partial least squares. In Evaluation of econometric models (pp. 47-74). Elsevier.

Wood, R., \& Bandura, A. (1989). Social cognitive theory of organizational management. Academy of Management Review, 14(3), 361-384.

Zhou, T., Lu, Y., \& Wang, B. (2010). Integrating TTF and UTAUT to explain mobile banking user adoption. Computers in Human Behavior, 26(4), 760-767. https://doi.org/10.1016/j.chb.2010.01.013 


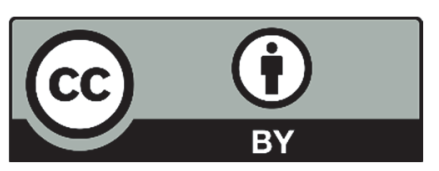

(C) 2020 by the authors; licensee Growing Science, Canada. This is an open access article distributed under the terms and conditions of the Creative Commons Attribution (CC-BY) license (http://creativecommons.org/licenses/by/4.0/). 